\title{
Impact of highway traffic and the acoustic screen on the content and spatial distribution of heavy metals in soils
}

\author{
Szymon Różański ${ }^{1}$ Hanna Jaworska ${ }^{1} \cdot$ Katarzyna Matuszczak $^{1} \cdot$ Joanna Nowak $^{1}$ • \\ Amber Hardy ${ }^{2}$
}

Received: 20 December 2016 / Accepted: 21 March 2017 /Published online: 30 March 2017

(C) The Author(s) 2017. This article is published with open access at Springerlink.com

\begin{abstract}
Recent years have witnessed intensification of road traffic and, with it, the amount of substances emitted by vehicles. Such emissions need to be monitored for public health purposes. The aim of this study was to evaluate the impact of the highway traffic on the total content and bioavailability of $\mathrm{Zn}, \mathrm{Cu}, \mathrm{Ni}, \mathrm{Cd}, \mathrm{Cr}$ and $\mathrm{Pb}$ in nearby soils as well as influence of an acoustic screen on spatial distribution of the metals. The material included 40 soil samples collected from 15 research points located 5, 10,25 and $50 \mathrm{~m}$ away from the road acoustic screen and from 4 points between the screen and the highway. Additionally, 5 research points were located next to the metal barrier. Selected physicochemical properties of soils were determined: soil texture, soil $\mathrm{pH}, \mathrm{TOC}$ and $\mathrm{CaCO}_{3}$ content. The total content of heavy metals in the soils was determined by AAS after digestion in aqua regia and bioavailable forms in $1 \mathrm{M}$ diethylenetriaminepentaacetic acid. The research found low impact of the highway traffic on the content of heavy metals in soils; however, due to a very short period of this potential impact ( 5 years), the moderately polluted category of geo-accumulation index of cadmium and high bioavailability of lead indicate the need of repeating the research within the next several years. Furthermore, the road acoustic screen
\end{abstract}

Responsible editor: Philippe Garrigues

Szymon Różański szymi@utp.edu.pl

1 Department of Soil Science and Soil Protection, Faculty of Agriculture and Biotechnology, UTP University of Science and Technology, Bernardynska St.6, 85-029 Bydgoszcz, Poland

2 Department of Natural Resources Science, Laboratory of Pedology and Soil Environmental Science, University of Rhode Island, Kingston, RI, USA significantly influenced spatial distribution of the metals in soils.

Keywords Heavy metals in soils · Highway traffic pollution · Geo-accumulation index

\section{Introduction}

The rise of mechanized transportation is associated with the development of road infrastructure. Road traffic is a major source of substances in the soil and atmosphere (Pallavi and Harrison 2013), including, among others, heavy metal compounds (Johanssona et al. 2009). The content of certain compounds in the soil is directly proportional to vehicle speed. Higher vehicle velocity causes increased emissions of exhaust containing, among other compounds, heavy metals (Duong and Lee 2011). Pollutant emissions must be monitored to preserve environmental quality and prevent its degradation (Franco et al. 2013).

In Poland, many highways are located along farmlands (Lewin et al. 2015). Pollution emitted by vehicles may be transported to these fields. There is a high risk of direct contamination of crops by heavy metals (Gill et al. 2014). The content of heavy metals in soil may be affected by natural (climate, soil processes) and anthropogenic factors such as agriculture and road traffic (Wei et al. 2007). Many studies have focused on total emission of heavy metals into agricultural areas (Hjortenkrans et al. 2006). The content of heavy metals in soils located along roads is strongly related to traffic and decreases with increasing distance from the road (Temmerman et al. 2003).

Uptake of heavy metals from soil by plants may be either passive or active (Kim et al. 2003). The main source of heavy metals in plants is road traffic (Gworek et al. 2011). Dynamic 
development of motorways and roads causes increasing content of heavy metals in many components of the environment (Blagojević et al. 2009). Automobiles, especially those used for freight, constitute an important source of heavy metals, especially lead, nickel and cadmium (Falahi-Ardakani 1984).

Heavy metals occurring in bedrock are mostly in stable forms and slowly undergo mobilisation during weathering processes (Karczewska and Kabała 2010). Soil pH, organic carbon content and clay content significantly impact the accumulation of heavy metals in soil (Malczyk and Kędzia 1996; Rosada 2007). The toxic effect of heavy metal pollution in soil is not just the result of the total content but also the chemical form of the element (Kabata-Pendias 2011). Diethylenetriaminepentaacetic acid (DTPA) is a common reagent used to determine the content of potentially bioavailable forms of metals in soils (Maiz et al. 2000; Dai et al. 2004; Feng et al. 2005). These forms constituted part of the total content (Elsokkary 1978), but many authors state these results are overestimated (McGrath 1996; Sterckeman et al. 1996). Heavy metals in the soil from anthropogenic sources tend to be more mobile than forms of pedogenic or lithogenic origin (Wuana and Okieimen 2011).

The aim of this study was to evaluate the impact of traffic in the vicinity of an acoustic screen on the spatial distribution of zinc $(\mathrm{Zn})$, copper $(\mathrm{Cu})$, nickel $(\mathrm{Ni})$, cadmium $(\mathrm{Cd})$, chromium $(\mathrm{Cr})$ and lead $(\mathrm{Pb})$ in soils intensively cultivated for food production after 5 years of highway running. It is widely known that concentration of heavy metals is the highest in soils close to roads and decreases with distance. It was assumed that the investigated screen, besides its acoustic role, also blocks wind. It is solid and therefore disturbs airflow, which may cause unpredictable impacts on the distribution of highway traffic contaminants in the analysed soils. Bioavailability of the metals in relation to the soil parameters was also assessed.

\section{Materials and methods}

\section{Description of the study area and soil sampling}

Research material was collected from soils along the A1 Grudziądz Highway (Poland) (53 21' 14.6" N $18^{\circ} 42^{\prime} 13.1^{\prime \prime}$ E). The investigated area was covered by Luvisols (IUSS 2014) formed from glacial till (Uniejewska 1982). The highway has been in use since 14 October 2011. The traffic intensity is over 17,000 vehicles per day (General Directorate 2015). There was an intensive small-scale cereal-livestock system with wheat in the year of sampling (in crop rotation with sugar beet and maize). Wind direction in the region is varied, with about $35 \%$ from the west, $25 \%$ from the east, $20 \%$ from the north and $20 \%$ from the south throughout the year (Woś 2010). Road acoustic screens are common constructions in Poland, protecting single houses, settlements or even cities in close vicinity of roads from noise. These barriers are usually made of steel, but also concrete or plastic. They are long - several dozen meters to many kilometres. The investigated screen was made of steel plates, about $650 \mathrm{~m}$ long and $4 \mathrm{~m}$ high.

The material included 40 soil samples collected from 15 research points located 5, 10, 25 and $50 \mathrm{~m}$ away from a road acoustic screen and from 4 points between the screen and the highway. Furthermore, 5 sampling points were located next to the metal barrier (Fig. 1). The distance between the points was $25 \mathrm{~m}$. Samples were taken using a hand auger from two depths: 0-20 cm (surface samples) and 20-40 cm (subsurface samples). The bucket was advanced to the appropriate depth and the contents (4 subsamples from each point) were transferred to a homogenization container for processing. The material was collected in July 2016 during 1 day of outdoor work.

\section{Laboratory and statistical analysis}

In the air-dried soil samples, crushed and passed through a 2$\mathrm{mm}$ sieve, the following analysis was conducted: $\mathrm{pH}$ using a glass electrode in a 1:5 (by volume) suspension of soil in deionized water $\left(\mathrm{pH}\right.$ in $\left.\mathrm{H}_{2} \mathrm{O}\right)$ and again in $1 \mathrm{M}$ potassium chloride solution ( $\mathrm{pH}$ in $\mathrm{KCl}$ ) (ISO 10390: 2005), total organic carbon content (TOC) by sulfochromic wet oxidation method in the potassium dichromate solution $-\mathrm{K}_{2} \mathrm{Cr}_{2} \mathrm{O}_{7}$ (ISO 14235: 1998), carbonate content in calcimeter according to the volumetric Scheibler's method and soil texture by sieving and sedimentation method (ISO 11277: 2009). The total content of heavy metals was determined using AAS method (SOLAR S4) after digestion in $3: 1 \mathrm{HCl}$ and $\mathrm{HNO}_{3}$ acids (aqua regia) (ISO 11466: 1995) and bioavailable forms after extraction with 1 M DTPA (Lindsay and Norvell 1978). The methods used are common in soil science laboratories. All analyses were conducted in three replicates and the validation of the results was based on the certified materials (reference soil sample TILL-3 and SO-4; Canada Centre for Mineral and Energy Technology). Pearson's correlation coefficient $(p<0.05)$ was used to explore relationships between the total content of analysed metals, their available forms and soil parameters, as well as ANOVA analysis for the total content of metals in surface horizon with the distance from the acoustic screen. Statistical analysis of the results was calculated in the Statistica 12.0 for Windows Pl software.

\section{Pollution index}

Geo-accumulation index (Igeo) (Müller 1969) makes an assessment of the impact of heavy metals on the soil environment (Saeedi et al. 2012; García-Martínez and Poleto 2014). Igeo (Müller 1969) was calculated as follows: 


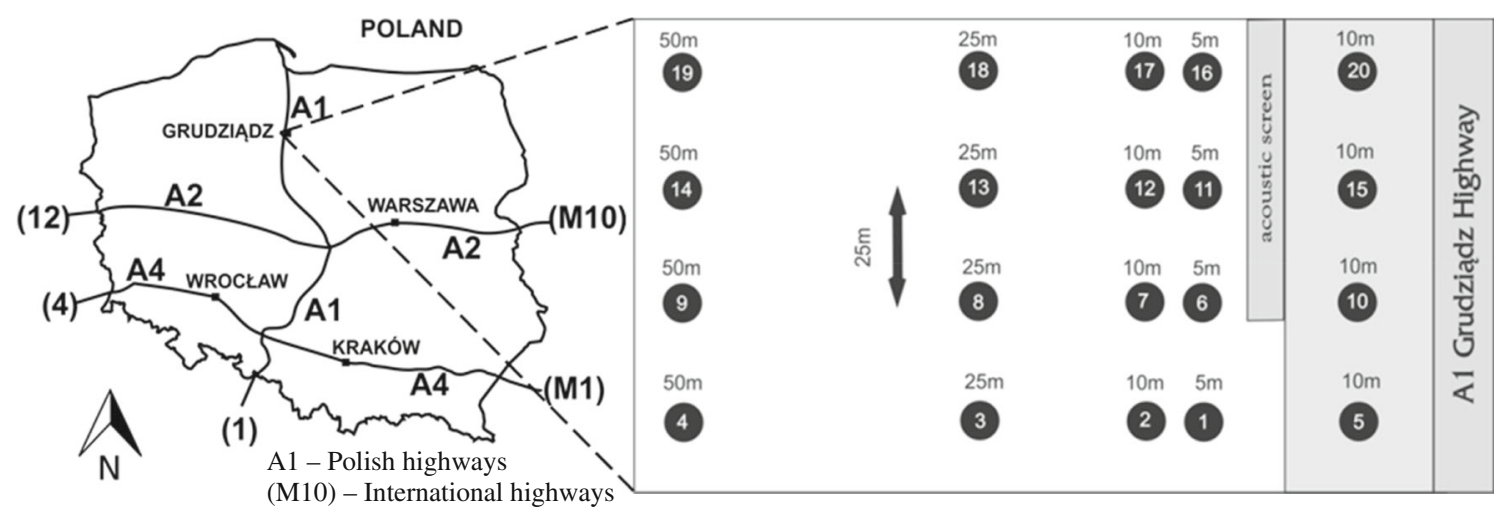

Fig. 1 Location of research points

Igeo $=\log \left(\frac{C \mathrm{~s}}{1.5 \times B \mathrm{n}}\right)$

where $C$ s refers to calculated values and $B \mathrm{n}$ to background values (Czarnowska 1996), the factor 1.5 is applied in order to control the variations of $B \mathrm{n}$ values caused by the environment. Shi et al. (2010) and García-Martínez and Poleto (2014) identified seven categories of Igeo, shown in Table 1.

Applied geochemical background values were from Czarnowska (1996), for glacial till as a parent material, of analysed soils as follows: $33.0 \mathrm{mg} \mathrm{kg}^{-1}(\mathrm{Zn}), 8.30 \mathrm{mg} \mathrm{kg}^{-1}$ (Cu), $11.0 \mathrm{mg} \mathrm{kg}^{-1}$ (Ni), $0.19 \mathrm{mg} \mathrm{kg}^{-1}$ (Cd), $26.0 \mathrm{mg} \mathrm{kg}^{-1}$ (Cr) and $10.3 \mathrm{mg} \mathrm{kg}^{-1}(\mathrm{~Pb})$.

\section{Results}

The analysis of texture allowed classification of the investigated soils into 2 texture classes: sandy loam and sandy clay loam (USDA 2012). The percentage of sand ranged from $57.0 \%$ to $72.0 \%$, silt from $16.0 \%$ to $26.0 \%$ and clay from $7.0 \%$ to $21.0 \%$. The content of total organic carbon (TOC) ranged from 1.8 to $10.7 \mathrm{~g} \mathrm{~kg}^{-1}$ in surface samples and from 0.9 to $9.3 \mathrm{~g} \mathrm{~kg}^{-1}$ in subsurface samples. In the analysed samples $\mathrm{pH}_{\mathrm{H} 2 \mathrm{O}}$ ranged from 6.0 to 8.0 , while $\mathrm{pH}_{\mathrm{KCl}}$ from 5.3 to 7.4. The content of $\mathrm{CaCO}_{3}$ ranged from $<1$ to $6.4 \%$ (Table 2).

The highest total content of heavy metals in analysed soils was seen in zinc (18.40-46.53 $\mathrm{mg} \mathrm{kg}^{-1}$ ) and chromium (15.98-31.88 $\left.\mathrm{mg} \mathrm{kg}^{-1}\right)$. The lowest total content was in lead (0.00-4.55 $\left.\mathrm{mg} \mathrm{kg}^{-1}\right)$ and cadmium (0.00-1.25 $\left.\mathrm{mg} \mathrm{kg}^{-1}\right)$ (Table 3).

The mean percentage of total metals that were in bioavailable forms were: $19.32 \%(\mathrm{Zn}), 11.35 \%(\mathrm{Cu}), 3.10 \%(\mathrm{Ni})$, $9.76 \%(\mathrm{Cd}), 2.88 \%(\mathrm{Cr})$ and $25.79 \%(\mathrm{~Pb})$.

Calculated correlation coefficients confirmed the significant relation between the content of clay and the total content of nickel $(r=0.489 ; p<0.05)$ (Fig. 2a) and bioavailable form of zinc $(r=-0.402 ; p<0.05)$ (Fig. 2b).
Significant coefficients calculated in ANOVA for the metal content in surface horizons and distance from the acoustic screen proved the influence of the screen on spatial distribution of the metals (Table 5).

Average geo-accumulation indexes took the following values: zinc -0.234 , copper -0.337 , nickel -0.347 , cadmium 0.292 , chromium -0.230 and lead -1.011 (Table 4).

\section{Discussion}

Soils generally had low total and bioavailable trace element contents. According to Polish guidelines (Regulation 2016), the tested area may qualify as unpolluted by the analysed metals. Moreover, determined values were characterised for uncontaminated soils of Europe (De Vivo et al. 1997; Salminen and Tarvainen 1997; Salminen and Gregorauskienè 2000; Sierra et al. 2007). The content of the metals followed the sequence: $\mathrm{Zn}>\mathrm{Cr}>\mathrm{Ni}>\mathrm{Cu}>\mathrm{Pb}>\mathrm{Cd}$. High concentrations of chromium (up to $47.49 \mathrm{mg} \mathrm{kg}^{-1}$ ) are typical for soils under agricultural and traffic influence, but then the content of lead is usually much higher (70.36 mg kg-1) than in the tested soils (Liu et al. 2013). The lower content of $\mathrm{Cr}$ is more characteristic of urban sites under different land uses - $\mathrm{Zn}>\mathrm{Cu}>\mathrm{Pb}>\mathrm{Cr}$ (TrujilloGonzález et al. 2016). Most urban soils have elevated values of cadmium, copper, lead and zinc like soils of Hong Kong (Li

Table 1 Geo-accumulation index (Müller 1969)

\begin{tabular}{ll}
\hline Value & Category \\
\hline Igeo $\leq 0$ & Unpolluted \\
$0<$ Igeo $<1$ & Unpolluted to moderately polluted \\
$1<$ Igeo $<2$ & Moderately polluted \\
$2<$ Igeo $<3$ & Moderately to highly polluted \\
$3<$ Igeo $<4$ & Highly polluted \\
$4<$ Igeo $<5$ & Highly to extremely polluted \\
Igeo $\geq 5$ & Extremely polluted \\
\hline
\end{tabular}


Table 2 Physicochemical properties of soil samples

\begin{tabular}{|c|c|c|c|c|c|c|}
\hline \multicolumn{2}{|c|}{ Soil sample and depth $(\mathrm{cm})$} & \multirow{2}{*}{$\frac{\mathrm{pH}_{\mathrm{H} 2 \mathrm{O}}}{7.6}$} & \multirow{2}{*}{$\frac{\mathrm{pH}_{\mathrm{KCl}}}{7.2}$} & \multirow{2}{*}{$\frac{\mathrm{TOC}\left(\mathrm{g} \mathrm{kg}^{-1}\right)}{3.8}$} & \multirow{2}{*}{$\frac{\mathrm{CaCO}_{3}(\%)}{<1}$} & \multirow{2}{*}{$\frac{\text { Clay }(\%)}{10.0}$} \\
\hline 1 & $0-20$ & & & & & \\
\hline & $20-40$ & 7.6 & 7.2 & 2.6 & $<1$ & 11.0 \\
\hline \multirow[t]{2}{*}{2} & $0-20$ & 7.0 & 6.5 & 8.6 & $<1$ & 10.0 \\
\hline & $20-40$ & 7.3 & 6.8 & 5.4 & $<1$ & 10.0 \\
\hline \multirow[t]{2}{*}{3} & $0-20$ & 7.1 & 6.5 & 4.2 & $<1$ & 11.0 \\
\hline & $20-40$ & 7.0 & 6.3 & 2.7 & $<1$ & 10.0 \\
\hline \multirow[t]{2}{*}{4} & $0-20$ & 7.1 & 6.5 & 2.7 & $<1$ & 17.0 \\
\hline & $20-40$ & 7.2 & 6.8 & 9.3 & $<1$ & 9.0 \\
\hline \multirow[t]{2}{*}{5} & $0-20$ & 7.4 & 7.1 & 9.3 & 1.3 & 14.0 \\
\hline & $20-40$ & 7.5 & 7.2 & 5.6 & 1.4 & 16.0 \\
\hline \multirow[t]{2}{*}{6} & $0-20$ & 7.4 & 7.1 & 3.9 & $<1$ & 21.0 \\
\hline & $20-40$ & 7.1 & 6.4 & 2.0 & $<1$ & 19.0 \\
\hline \multirow[t]{2}{*}{7} & $0-20$ & 7.4 & 7.0 & 2.9 & $<1$ & 7.0 \\
\hline & $20-40$ & 7.1 & 6.3 & 1.9 & $<1$ & 15.0 \\
\hline \multirow[t]{2}{*}{8} & $0-20$ & 7.3 & 6.9 & 2.1 & $<1$ & 9.0 \\
\hline & $20-40$ & 7.2 & 6.8 & 3.2 & $<1$ & 12.0 \\
\hline \multirow[t]{2}{*}{9} & $0-20$ & 7.6 & 7.2 & 1.8 & 4,6 & 14.0 \\
\hline & $20-40$ & 7.7 & 7.3 & 1.5 & 5.3 & 17.0 \\
\hline \multirow[t]{2}{*}{10} & $0-20$ & 7.6 & 7.3 & 4.6 & 1.4 & 13.0 \\
\hline & $20-40$ & 8.0 & 7.4 & 0.9 & 5.6 & 12.0 \\
\hline \multirow[t]{2}{*}{11} & $0-20$ & 7.2 & 6.9 & 5.5 & $<1$ & 10.0 \\
\hline & $20-40$ & 7.1 & 6.6 & 4.0 & $<1$ & 9.0 \\
\hline \multirow[t]{2}{*}{12} & $0-20$ & 7.3 & 7.1 & 7.7 & $<1$ & 7.0 \\
\hline & $20-40$ & 7.3 & 7.0 & 6.5 & $<1$ & 8.0 \\
\hline \multirow[t]{2}{*}{13} & $0-20$ & 7.5 & 7.1 & 6.3 & 1.3 & 12.0 \\
\hline & $20-40$ & 7.5 & 7.2 & 7.6 & 1.5 & 10.0 \\
\hline \multirow[t]{2}{*}{14} & $0-20$ & 7.3 & 6.8 & 4.6 & $<1$ & 12.0 \\
\hline & $20-40$ & 7.2 & 6.8 & 4.9 & $<1$ & 10.0 \\
\hline \multirow[t]{2}{*}{15} & $0-20$ & 7.8 & 7.3 & 1.9 & 2.3 & 13.0 \\
\hline & $20-40$ & 7.7 & 7.3 & 1.5 & 2.8 & 12.0 \\
\hline \multirow[t]{2}{*}{16} & $0-20$ & 7.1 & 6.8 & 4.3 & $<1$ & 8.0 \\
\hline & $20-40$ & 7.2 & 6.8 & 5.7 & $<1$ & 9.0 \\
\hline \multirow[t]{2}{*}{17} & $0-20$ & 6.0 & 5.3 & 6.9 & $<1$ & 10.0 \\
\hline & $20-40$ & 6.4 & 5.6 & 5.6 & $<1$ & 9.0 \\
\hline \multirow[t]{2}{*}{18} & $0-20$ & 7.4 & 7.2 & 4.9 & 1.3 & 13.0 \\
\hline & $20-40$ & 7.7 & 7.3 & 6.2 & 3.9 & 15.0 \\
\hline \multirow[t]{2}{*}{19} & $0-20$ & 6.9 & 6.8 & 10.7 & $<1$ & 19.0 \\
\hline & $20-40$ & 7.4 & 6.6 & 3.9 & $<1$ & 15.0 \\
\hline \multirow[t]{2}{*}{20} & $0-20$ & 7.6 & 7.2 & 3.6 & 2.0 & 11.0 \\
\hline & $20-40$ & 7.9 & 7.3 & 2.9 & 6.4 & 17.0 \\
\hline
\end{tabular}

et al. 2001), or even exceed the limits, like in soils of Naples (Italy) in the case of lead, cadmium and zinc (Imperato et al. 2003). In the investigated soils, there were almost none significant correlations between total content of the metals and soil parameters. Only nickel was positively correlated with clay content $(r=0.489 ; p<0.05)$ (Fig. $2 \mathrm{a})$, which indicates the significant role of clay minerals in bonding of this metal (Kabata-Pendias 2011).
In research conducted in Istanbul close to the E-5 Highway, heavy metals such as $\mathrm{Pb}, \mathrm{Cu}, \mathrm{Mn}, \mathrm{Cd}$ and $\mathrm{Ni}$ have been detected in street dust (Sezgin et al. 2004). In roadside soils of Damascus, lead concentration ranged from 78.4 to $832.0 \mathrm{mg}$ $\mathrm{kg}^{-1}$ (Othman et al. 1997), and in soils along A-8 Highway in Gipuzkoa (Spain), remarkable high levels of zinc and lead were determined (Garcia and Millán 1998). Other research showed that the content of heavy metals in soil samples from 
Table 3 The total content and bioavailable forms of heavy metals in soil samples $\left(\mathrm{mg} \mathrm{kg}^{-1}\right)$

\begin{tabular}{|c|c|c|c|c|c|c|c|c|c|c|c|c|c|}
\hline \multicolumn{2}{|c|}{ Soil sample and depth $(\mathrm{cm})$} & \multicolumn{2}{|l|}{$\mathrm{Zn}$} & \multicolumn{2}{|l|}{$\mathrm{Cu}$} & \multicolumn{2}{|l|}{$\mathrm{Ni}$} & \multicolumn{2}{|l|}{$\mathrm{Cd}$} & \multicolumn{2}{|l|}{$\mathrm{Cr}$} & \multicolumn{2}{|l|}{$\mathrm{Pb}$} \\
\hline & & Total & DTPA & Total & DTPA & Total & DTPA & Total & DTPA & Total & DTPA & Total & DTPA \\
\hline \multirow[t]{2}{*}{1} & $0-20$ & 34.25 & 2.03 & 5.70 & 0.75 & 6.98 & 0.35 & 0.33 & b.d.l. & 19.68 & 1.16 & 1.55 & 0.39 \\
\hline & $20-40$ & 34.88 & 6.98 & 6.10 & 0.88 & 5.93 & 0.31 & 0.25 & b.d.1. & 22.50 & 0.13 & 2.53 & 0.72 \\
\hline \multirow[t]{2}{*}{2} & $0-20$ & 29.03 & 2.22 & 6.00 & 0.79 & 3.40 & 0.20 & 0.90 & b.d.1. & 20.15 & 0.84 & 1.30 & 0.18 \\
\hline & $20-40$ & 23.43 & 3.10 & 6.58 & 0.83 & 6.40 & 0.32 & 0.30 & b.d.l. & 21.45 & 1.00 & 2.10 & 0.38 \\
\hline \multirow[t]{2}{*}{3} & $0-20$ & 20.25 & 2.57 & 7.20 & 1.14 & 5.85 & 0.33 & 0.53 & 0.03 & 17.85 & 0.66 & 3.75 & 0.36 \\
\hline & $20-40$ & 19.80 & 4.23 & 7.48 & 1.03 & 10.18 & 0.50 & 1.18 & b.d.l. & 15.98 & 0.28 & 2.85 & 0.23 \\
\hline \multirow[t]{2}{*}{4} & $0-20$ & 20.23 & 1.55 & 8.13 & 0.62 & 5.65 & 0.29 & 1.03 & b.d.l. & 18.58 & 0.41 & 1.55 & 0.42 \\
\hline & $20-40$ & 18.40 & 3.11 & 8.28 & 0.77 & 7.05 & 0.33 & 1.18 & b.d.l. & 19.78 & 0.52 & 1.68 & 0.67 \\
\hline \multirow[t]{2}{*}{5} & $0-20$ & 25.48 & 1.81 & 8.88 & 0.69 & 8.85 & 0.22 & 1.03 & b.d.1. & 22.13 & 0.48 & 2.28 & 0.38 \\
\hline & $20-40$ & 27.30 & 1.01 & 9.78 & 0.80 & 9.80 & 0.18 & 0.70 & 0.03 & 21.58 & 0.79 & 3.08 & 0.66 \\
\hline \multirow[t]{2}{*}{6} & $0-20$ & 31.28 & 0.56 & 4.85 & 0.43 & 13.28 & b.d.l. & b.d.l. & 0.20 & 26.85 & 0.79 & b.d.l. & b.d.l. \\
\hline & $20-40$ & 30.73 & 0.57 & 5.50 & 0.36 & 11.28 & 0.17 & 0.10 & 0.19 & 26.60 & 0.99 & b.d.l. & b.d.1. \\
\hline \multirow[t]{2}{*}{7} & $0-20$ & 30.08 & 1.13 & 5.13 & 0.59 & 13.13 & 0.24 & 0.10 & 0.16 & 30.35 & 0.45 & b.d.l. & b.d.l. \\
\hline & $20-40$ & 32.20 & 0.87 & 5.15 & 0.51 & 9.60 & 0.20 & 0.12 & 0.19 & 22.13 & 0.80 & b.d.l. & b.d.l. \\
\hline \multirow[t]{2}{*}{8} & $0-20$ & 25.55 & 0.76 & 4.38 & 0.39 & 4.33 & 0.05 & b.d.l. & 0.13 & 19.25 & 0.72 & b.d.l. & b.d.l. \\
\hline & $20-40$ & 26.23 & 0.59 & 4.58 & 0.43 & 8.58 & 0.06 & b.d.l. & 0.13 & 20.88 & 1.05 & 0.88 & 0.58 \\
\hline \multirow[t]{2}{*}{9} & $0-20$ & 27.13 & 0.86 & 5.83 & 0.56 & 11.38 & 0.31 & b.d.l. & 0.07 & 31.88 & 0.76 & b.d.l. & b.d.l. \\
\hline & $20-40$ & 23.85 & 14.37 & 4.98 & 0.57 & 9.33 & 0.05 & 0.38 & 0.07 & 23.90 & 1.12 & b.d.l. & b.d.l. \\
\hline \multirow[t]{2}{*}{10} & $0-20$ & 25.25 & 12.04 & 5.70 & 0.63 & 6.50 & 0.16 & b.d.1. & b.d.1. & 26.65 & 0.47 & b.d.l. & b.d.l. \\
\hline & $20-40$ & 24.65 & 2.76 & 5.85 & 0.64 & 7.73 & b.d.l. & 0.18 & b.d.1. & 29.43 & 0.26 & b.d.l. & b.d.l. \\
\hline 11 & $0-20$ & 24.28 & 14.20 & 6.63 & 0.50 & 7.83 & 0.22 & 0.18 & b.d.1. & 26.18 & 0.61 & 0.25 & 0.11 \\
\hline & $20-40$ & 24.88 & 12.24 & 6.93 & 0.62 & 3.40 & 0.15 & b.d.1. & 0.04 & 19.68 & 0.98 & 1.13 & 0.88 \\
\hline 12 & $0-20$ & 28.48 & 16.68 & 4.10 & 0.44 & 7.18 & 0.12 & b.d.1. & 0.06 & 27.45 & 0.45 & 1.60 & 1.02 \\
\hline & $20-40$ & 26.10 & 12.15 & 7.63 & 0.52 & 7.93 & 0.06 & 0.08 & 0.05 & 27.43 & 0.32 & 1.35 & 0.99 \\
\hline 13 & $0-20$ & 37.05 & 13.45 & 9.15 & 0.53 & 8.30 & 0.16 & b.d.1. & b.d.l. & 30.25 & 0.56 & 1.55 & 1.14 \\
\hline & $20-40$ & 36.78 & 14.90 & 8.30 & 0.50 & 5.18 & 0.65 & 0.85 & b.d.l. & 25.48 & 1.06 & 3.03 & 1.58 \\
\hline 14 & $0-20$ & 24.73 & 1.18 & 6.65 & 0.75 & 6.13 & 0.20 & 0.75 & b.d.l. & 24.38 & 0.73 & 1.80 & 0.90 \\
\hline & $20-40$ & 21.38 & 15.78 & 7.80 & 0.80 & 5.95 & 0.13 & 0.50 & b.d.l. & 24.18 & 0.35 & 2.70 & 0.88 \\
\hline 15 & $0-20$ & 22.60 & 1.56 & 7.73 & 0.85 & 7.45 & 0.24 & 0.63 & b.d.l. & 27.00 & 0.84 & 0.55 & 0.42 \\
\hline & $20-40$ & 24.23 & 0.88 & 8.18 & 0.74 & 4.15 & 0.33 & 1.25 & b.d.l. & 23.33 & 1.09 & 4.38 & 0.96 \\
\hline 16 & $0-20$ & 42.30 & 15.94 & 3.25 & 1.11 & 6.70 & 0.25 & b.d.1. & b.d.l. & 16.38 & 0.67 & 4.55 & b.d.l. \\
\hline & $20-40$ & 24.30 & 18.76 & 2.88 & 1.43 & 9.33 & 0.56 & b.d.l. & b.d.l. & 19.63 & 0.45 & 3.95 & 0.35 \\
\hline 17 & $0-20$ & 27.85 & 1.59 & 2.90 & 0.92 & 8.10 & 0.29 & b.d.1. & b.d.1. & 19.88 & 0.84 & 2.53 & 0.46 \\
\hline & $20-40$ & 26.88 & 1.46 & 3.93 & 0.78 & 4.80 & 0.16 & 0.15 & b.d.1. & 19.05 & 0.76 & 3.10 & 0.52 \\
\hline 18 & $0-20$ & 34.50 & 8.94 & 5.00 & 0.69 & 8.45 & 0.42 & 0.10 & b.d.l. & 20.78 & 0.31 & 0.43 & 0.41 \\
\hline & $20-40$ & 41.38 & 2.25 & 6.05 & 0.68 & 8.95 & 0.44 & 0.15 & b.d.l. & 24.75 & 0.50 & 1.68 & 0.81 \\
\hline 19 & $0-20$ & 46.53 & 1.24 & 6.33 & 0.67 & 9.90 & 0.46 & b.d.l. & b.d.l. & 20.25 & 0.20 & 2.35 & 0.38 \\
\hline & $20-40$ & 41.28 & 1.06 & 7.38 & 0.68 & 11.95 & 0.31 & 0.53 & b.d.l. & 26.43 & 0.56 & 2.28 & 0.65 \\
\hline 20 & $0-20$ & 36.08 & 4.34 & 5.38 & 0.86 & 8.85 & 0.27 & 0.40 & b.d.l. & 21.50 & 0.76 & 2.48 & 0.40 \\
\hline & $20-40$ & 37.98 & 1.91 & 8.10 & 0.73 & 9.88 & 0.06 & 0.45 & b.d.l. & 21.45 & 0.85 & 3.95 & 0.11 \\
\hline Mean & $0-20$ & 29.65 & 5.23 & 5.95 & 0.70 & 7.91 & 0.24 & 0.30 & 0.03 & 23.37 & 0.64 & 1.43 & 0.35 \\
\hline & $20-40$ & 28.33 & 5.95 & 6.57 & 0.72 & 7.87 & 0.25 & 0.42 & 0.04 & 22.78 & 0.69 & 2.03 & 0.55 \\
\hline Min & $0-20$ & 20.23 & 0.56 & 2.90 & 0.39 & 3.40 & b.d.1. & b.d.1. & b.d.l. & 16.38 & 0.20 & b.d.l. & b.d.l. \\
\hline & $20-40$ & 18.40 & 0.57 & 2.88 & 0.36 & 3.40 & b.d.l. & b.d.1. & b.d.l. & 15.98 & 0.13 & b.d.l. & b.d.l. \\
\hline Max & $0-20$ & 46.53 & 16.68 & 9.15 & 1.14 & 13.28 & 0.46 & 1.03 & 0.20 & 31.88 & 1.16 & 4.55 & 1.14 \\
\hline & $20-40$ & 41.38 & 18.76 & 9.78 & 1.43 & 11.95 & 0.65 & 1.25 & 0.19 & 29.43 & 1.12 & 4.38 & 1.58 \\
\hline SD & $0-20$ & 7.01 & 5.82 & 1.70 & 0.21 & 2.57 & 0.11 & 0.38 & 0.06 & 4.63 & 0.22 & 1.31 & 0.34 \\
\hline & $20-40$ & 6.89 & 6.19 & 1.73 & 0.23 & 2.42 & 0.18 & 0.41 & 0.06 & 3.29 & 0.32 & 1.39 & 0.42 \\
\hline
\end{tabular}

b.d.l. below detection limit

local roads was much higher than in samples along highways (Huber et al. 2016). Concentration of pollutants in soils is also affected by traffic volume (Horstmeyer et al. 2016) as well as the speed of vehicles (Duong and Lee 2011). So possibly the emission of exhaust in traffic jams is even higher than during high speed transportation. Other factors like construction of the road, velocity and direction of air flow (wind) or infrastructure along the road may also influence the concentration of pollutants in soils. Undoubtedly, automobiles constitute the main source of heavy metals in roadside soils (Aslam et al. 2013). In comparison to other Polish highways, the investigated road classifies as a medium traffic road, with 17,188 vehicles/day. The mean traffic volume on international Polish roads in 2015 was 20,067 vehicles/day, with a maximum of up to 100,983 vehicles/day (General Directorate 2015). In combination with the relatively short time of contamination source impact, the effect may be imperceptible. However, the comparative research conducted in Poland (Gliwice and 

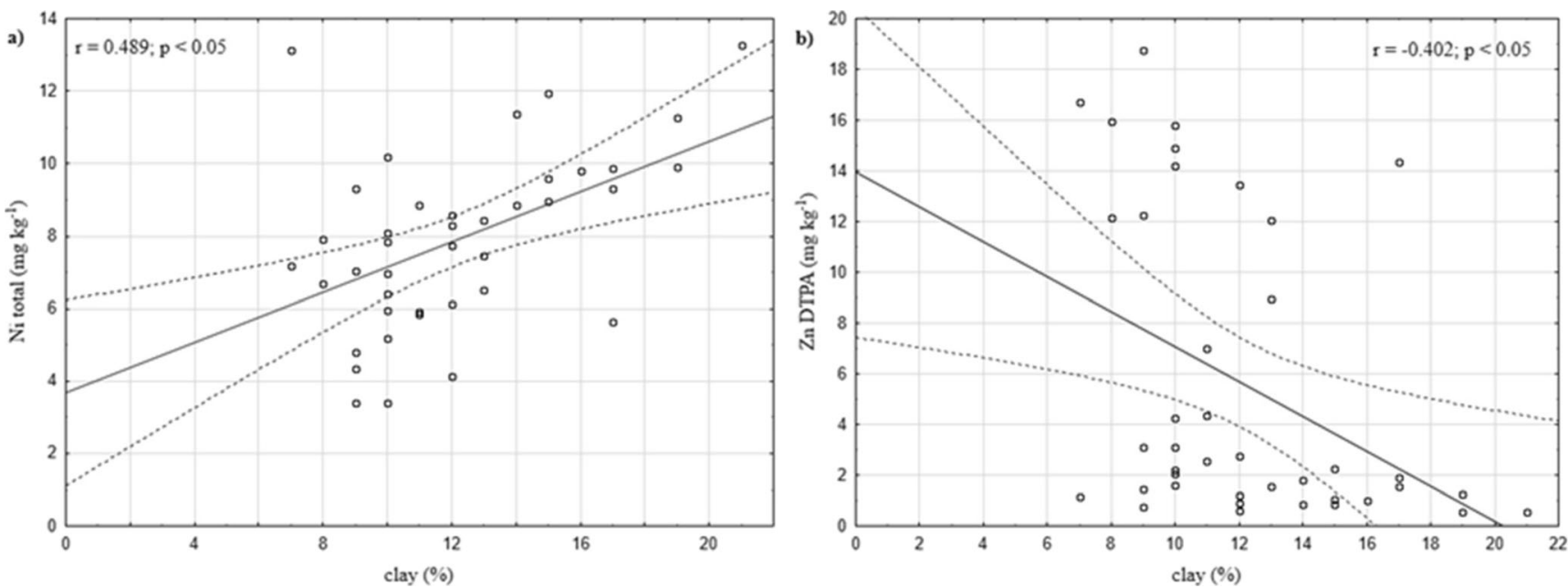

Fig. 2 Correlation with a significant relationship between the clay content and the total content of nickel (a) and bioavailable form of zinc (b)

Opole), Germany (Tübingen, Ulm and Böblingen), Finland (Helsinki), Tajikistan (Dushanbe) and China (Lanzhou) showed significant increase of $\mathrm{Zn}, \mathrm{Pb}, \mathrm{Cd}$ and $\mathrm{Cu}$ content on test-monitoring plots installed next to the road edge for 24 months (Wawer et al. 2015). These amounts depended on place and element and were about $2-50 \mathrm{mg} \mathrm{kg}^{-1}$ year ${ }^{-1}$ for $\mathrm{Zn}, 0-30 \mathrm{mg} \mathrm{kg}^{-1}$ year $^{-1}$ for $\mathrm{Pb}, 0-2 \mathrm{mg} \mathrm{kg}^{-1}$ year $^{-1}$ for $\mathrm{Cd}$ and $1-24 \mathrm{mg} \mathrm{kg}^{-1}$ year $^{-1}$ for $\mathrm{Cu}$. It indicates that the potential accumulation of these pollutants may be noticeable but of course dependent on many other factors responsible for metal bonding (soil properties, form of the metal etc.).

Assessing the metal concentration according to the calculated geo-accumulation index, the investigated soils may be classified from unpolluted to moderately polluted. The higher value of this index was determined for $\mathrm{Cd}$ (max. 0.556); in all other cases, negative values were noted (Table 4). TrujilloGonzález et al. (2016) reported that in the highway soils the geo-accumulation index took the following mean values: $\mathrm{Pb}$ $0.8, \mathrm{Ni}-2.1, \mathrm{Zn} 0.5, \mathrm{Cu} 0.9$ and $\mathrm{Cr} 2.7$. Another study showed that the mean Igeo index in commercial soils of Shanghai was 2.3 for $\mathrm{Pb}, 1.5$ for $\mathrm{Cu}$ and 2.4 for $\mathrm{Zn}$ (Shi et al. 2010). This indicates that the geo-accumulation index depends on the type of traffic sectors (commercial, residential or highway). Many studies confirmed that Igeo is higher in commercial sectors than in the highway sectors (Shi et al. 2010; Wei and Yang 2010). So, the obtained index may prove that highway traffic did not have a significant influence on the content of heavy

Table 4 Calculated geo-accumulation indexes (Igeo)

\begin{tabular}{lrrrrrr}
\hline & \multicolumn{1}{l}{$\mathrm{Zn}$} & $\mathrm{Cu}$ & $\mathrm{Ni}$ & $\mathrm{Cd}$ & \multicolumn{1}{l}{$\mathrm{Cr}$} & \multicolumn{1}{l}{$\mathrm{Pb}$} \\
\hline Mean & -0.234 & -0.337 & -0.347 & 0.292 & -0.230 & -1.011 \\
Min & -0.389 & -0.633 & -0.690 & -0.212 & -0.377 & -1.791 \\
Max & -0.027 & -0.089 & -0.098 & 0.556 & -0.088 & -0.531 \\
SD & 0.098 & 0.136 & 0.143 & 0.258 & 0.085 & 0.345 \\
\hline
\end{tabular}

metals in soil. Furthermore, Igeo index showed that the acoustic road screen and distance from the highway also did not impact the content of heavy metals in soils. Moreover, the screen installed along A1 Grudziądz Highway did not stop migration of pollutants. This situation was difficult to assess because the investigated highway has been in use since 14 October 2011, so the period of potential impact is very short. Research conducted by Hofman and Wachowski (2010) on new section of A2 Highway (Poznań) which has been in use since 2003 showed low concentration of lead not exceeding the permissible standards. A different result was obtained by Czarnowska (1994) in soils located along exit roads of Warsaw. This research showed contamination by lead in a 30-m zone away from these roads. A reason for this could be the retraction of leaded gasoline in Poland in February 2005. A similar study demonstrated that traffic had an effect on the accumulation of $\mathrm{Zn}, \mathrm{Pb}, \mathrm{Cd}$ and $\mathrm{Cu}$ in soils at least at distances up to $50 \mathrm{~m}$ (Czarnowska et al. 2002).

On the basis of ANOVA the relationship between the distance from the acoustic screen and the concentration of analysed metals in surface horizons was confirmed (Table 5). Significant coefficients showed a slight trend in spatial distribution of investigated metals. The highest average

Table 5 The content of analysed metals and distance from the acoustic screen

\begin{tabular}{llllllll}
\hline & Distance & $\mathrm{Zn}$ & $\mathrm{Cu}$ & $\mathrm{Ni}$ & $\mathrm{Cd}$ & $\mathrm{Cr}$ & $\mathrm{Pb}$ \\
\hline Mean & $10 \mathrm{~m}^{\mathrm{a}}$ & 27.353 & 6.923 & 7.913 & 0.515 & 24.320 & 1.328 \\
& $5 \mathrm{~m}$ & 33.028 & 5.108 & 8.698 & 0.083 & 22.273 & 1.588 \\
& $10 \mathrm{~m}$ & 28.860 & 4.533 & 7.953 & 0.363 & 24.458 & 1.358 \\
& $25 \mathrm{~m}$ & 29.338 & 6.433 & 6.733 & 0.270 & 22.031 & 1.433 \\
& $50 \mathrm{~m}$ & 29.655 & 6.735 & 8.265 & 0.445 & 23.773 & 1.425 \\
& LSD $_{0.05}$ & 0.074 & 0.125 & 0.103 & 0.315 & 0.020 & 0.073 \\
\hline
\end{tabular}

${ }^{\mathrm{a}}$ Between the screen and the highway 
concentrations were noticed 5 and $50 \mathrm{~m}$ away from the screen. In comparison to standard distribution of traffic contaminants in soils along the roads, where concentration decrease with distance, and reach natural levels $30-50 \mathrm{~m}$ away (Czarnowska 1994; Temmerman et al. 2003; Werkenthin et al. 2014), the impact of the acoustic screen as a wind barrier is noticeable. Directly behind the barrier turbulences may form, where contaminants on suspended particles (dusts, aerosols), especially coarse ones, deposit. In the next 10-25 m, the wind velocity decreases and at a distance of $50 \mathrm{~m}$ is slow enough for deposition of fine fractions. The effect is not very distinct because the metal enrichment in not high, mostly because of the short time of impact ( 5 years). The low concentration of metals in the zone between the highway and the screen also confirms this, because this area is the most exposed for pollution additionally by runoff and splash water from the road (Werkenthin et al. 2014).

In the research conducted in the roadside soils by Garcia et al. (1996), highly significant correlations between the total content of cadmium, copper, zinc and lead and their bioavailable forms extracted with DTPA were noted. In this study, there did not seem to be a relationship between bioavailability and total content of the metals. Other researchers reported that lead and copper are not highly mobile metals (Pagotto et al. 2001). The study conducted by Legret and Pagotto (2006) showed that lead is the metal of high bioavailability in roadside soils. It has also been confirmed in this study_lead was the most bioavailable, mobile element-mean $\mathrm{Pb}_{\text {DTPA }}$ $25.79 \%$. Due to very low total content of $\mathrm{Pb}$, even such high mobility of this element is low risk for the environment. However, areas along the highways are mostly agricultural lends, focused on food production, so they should stay under especial control as to the level of pollutants. Another element of relatively high bioavailability was zinc $(19.32 \%)$, whereas concentration of the forms of copper $(11.35 \%)$ may lead to deficiency of the element for the plants. The rest of the analysed metals were characterised by low mobility - cadmium $(9.76 \%)$, nickel $(3.10 \%)$ and chromium $(2.88 \%)$. Calculated correlations were significant only for bioavailable forms of $\mathrm{Zn}$ and clay content ( $r=-0.402 ; p<0.05)$ (Fig. 2b). This negative relation indicates on crucial role of clay minerals in bonding of zinc in investigated soils. Increase of clay content leads to decrease of mobile forms of $\mathrm{Zn}$.

\section{Conclusion}

In the studied soils, natural content of analysed heavy metals was determined to be characteristic for unpolluted soils of Poland. The research confirmed low impact of the highway traffic on the content of heavy metals in soils. However, the very short period of this potential impact ( 5 years), the moderately polluted category of geo-accumulation index of cadmium, and high bioavailability of lead indicate the need to repeat the research within several years. Furthermore, the role of the road acoustic screen in spatial distribution of analysed metals was noticed. This barrier did not stop migration of pollutants but influenced significantly the place of deposition. Statistically the highest concentrations of the metals were found 5 and $50 \mathrm{~m}$ behind the screen. In comparison to other research on soils under traffic influence, the distance from the road edge where accumulation takes place is higher with acoustic screens. This is the effect of wind disturbances created by the investigated acoustic screen.

Open Access This article is distributed under the terms of the Creative Commons Attribution 4.0 International License (http:// creativecommons.org/licenses/by/4.0/), which permits unrestricted use, distribution, and reproduction in any medium, provided you give appropriate credit to the original author(s) and the source, provide a link to the Creative Commons license, and indicate if changes were made.

\section{References}

Aslam J, Khan SA, Khan SH (2013) Heavy metals contamination in roadside soil near different traffic signals in Dubai, United Arab Emirates. J Saudi Chem Soc 17(3):315-319. doi:10.1016/j.jscs.2011.04.015

Blagojević N, Damjanović-Vratnica B, Vukašinović-Pešić V, Đurović D (2009) Heavy metals content in leaves and extracts of wild-growing Salvia officinalis from Montenegro. Pol J Environ Stud 18(2):167-173

Czarnowska K (1994) Accumulation of heavy metals in agricultural soils and celery leaves near roads around Warsaw. Soil Sci Ann 45(3/4):59-75

Czarnowska K (1996) General content of heavy metals in bedrock as a geochemical background of soil. Soil Sci Ann 47:43-50

Czarnowska K, Chlibiuk M, Kozanecka T (2002) Trace elements in arable soils near roads around Warsaw. Soil Sci Ann 53(3/4):67-74

Dai J, Becquer T, Rouiller JH, Reversat G, Bernhard-Reversat F, Nahmani J, Lavelle P (2004) Heavy metal accumulation by two earthworm species and its relationship to total and DTPA extractable metals in soils. Soil Biol Biochem 36(1):91-98. doi:10.1016/j. soilbio.2003.09.001

De Vivo B, Boni M, Marcello A, Di Bonito M, Russo A (1997) Baseline geochemical mapping of Sardinia (Italy). J Geochem Explor 60(1): 77-90. doi:10.1016/S0375-6742(97)00027-7

Duong TT, Lee BK (2011) Determining contamination level of heavy metals in road dust from busy traffic areas with different characteristics. J Environ Manag 92(3):554-562. doi:10.1016/j.jenvman.2010.09.010

Elsokkary IH (1978) Contamination of roadside soils and plants near highway traffic with $\mathrm{Cd}, \mathrm{Ni}, \mathrm{Pb}$ and $\mathrm{Zn}$ in Alexandria district, Egypt. Studies in Environmental Science 1:25-28. doi:10.1016/ S0166-1116(08)71540-1

Falahi-Ardakani A (1984) Contamination of environment with heavy metals emitted from automotives. Ecotox Environ Safe 8(2):152161. doi:10.1016/0147-6513(84)90057-5

Feng MH, Shan XQ, Zhang S, Wen B (2005) A comparison of the rhizosphere-based method with DTPA, EDTA, $\mathrm{CaCl}_{2}$, and $\mathrm{NaNO}_{3}$ extraction methods for prediction of bioavailability of metals in soil to barley. Environ Pollut 137(2):231-240. doi:10.1016/j.envpol. 2005.02 .003

Franco V, Kousoulidou M, Muntean M, Ntziachristos L, Hausberger S, Dilara P (2013) Road vehicle emission factors development: a review. Atmos Environ 70:84-97. doi:10.1016/j.atmosenv.2013.01.006 
Garcia R, Maiz I, Millán E (1996) Heavy metal contamination analysis of roadsoils and grasses from Gipuzkoa (Spain). Environ Technol 17: 763-770. doi:10.1080/09593331708616443

Garcia R, Millán E (1998) Assessment of Cd, Pb and Zn contamination in roadside soils and grasses from Gipuzkoa (Spain). Chemosphere 37(8):1615-1625. doi:10.1016/S0045-6535(98)00152-0

García-Martínez LL, Poleto C (2014) Assessment of diffuse pollution associated with metals in urban sediments using the geoaccumulation index (Igeo). J Soil Sci 1-7. doi: 10.1007/ s11368-014-0871-y

General Directorate of National Roads and Motorways (2015) General traffic measurement in Poland. Government Agency, WarsawReport

Gill LW, Ring P, Higgins MP, Johnston PM (2014) Accumulation of heavy metals in a constructed wetland treating road runoff. Ecol Eng 70:133-139. doi:10.1016/j.ecoleng.2014.03.056

Gworek B, Deckowska A, Pierscieniak M (2011) Traffic pollutant indicator: common dandelion (Teraxacum Officinale), Scots pine (Pinus Silvestris), small-leavud lime (Tilia cordata). Pol J Environ Stud 20(1):87-92

Hjortenkrans D, Bergbäck B, Häggerud A (2006) New metal emission patterns in road traffic environments. Environ Monit Assess 117(1): 85-98. doi:10.1007/s10661-006-7706-2

Hofman M, Wachowski L (2010) Soil concentrations of platinum and lead along the main exit routes from the city of Poznan. Environ Prot 32(3):43-47

Horstmeyer N, Huber M, Drewes JE, Helmreich B (2016) Evaluation of site-specific factors influencing heavy metal contents in the topsoil of vegetated infiltration swales. Sci Total Environ 560:19-28. doi: 10.1016/j.scitotenv.2016.04.051

Huber M, Welker A, Helmreich B (2016) Critical review of heavy metal pollution of traffic area runoff: occurrence, influencing factors, and partitioning. Sci Total Environ 541:895-919. doi:10.1016/j. scitotenv.2015.09.033

Imperato M, Adamo P, Naimo D, Arienzo M, Stanzione D, Violante P (2003) Spatial distribution of heavy metals in urban soils of Naples city (Italy). Environ Pollut 124(2):247-256. doi:10.1016/S02697491(02)00478-5

ISO 10390 (2005) Soil quality - Determination of $\mathrm{pH}$

ISO 11277 (2009) Soil quality - determination of particle size distribution in mineral soil material - method by sieving and sedimentation

ISO 11466 (1995) Soil quality - extraction of trace elements soluble in aqua regia

ISO 14235 (1998) Soil quality - determination of organic carbon by sulfochromic oxidation

IUSS Working Group WRB (2014) World Reference Base for Soil Resources 2014. International soil classification system for naming soils and creating legends for soil maps. World Soil Resources Reports No. 106. FAO, Rome

Johanssona C, Norman M, Burman L (2009) Road traffic emission factors for heavy metals. Atmos Environ 43(31):4681-4688. doi:10. 1016/j.atmosenv.2008.10.024

Kabata-Pendias A (2011) Trace elements in soils and plants. Fourth Edition. CRC Press Taylor \& Francis Group

Karczewska A, Kabała C (2010) The soils polluted with heavy metals and arsenic in Lower Silesia - the need and methods of reclamation. Scientific Journal of Wrocław University of Environmental and Life Science Series of Agronomy 576:59-79

Kim IS, Kang HK, Johnson-Green P, Lee EJ (2003) Investigation of heavy metal accumulation in Polygonum thunbergii for phytoextraction. Environ Pollut 126(2):235-243. doi:10.1016/ S0269-7491(03)00190-8

Legret M, Pagotto C (2006) Heavy metal deposition and soil pollution along two major rural highways. Environ Technol 27(3):247-254. doi:10.1080/09593332708618641
Lewin I, Spyra A, Krodkiewska M, Strzelec M (2015) The importance of the mining subsidence reservoirs located along the trans-regional highway in the conservation of the biodiversity of freshwater molluscs in industrial areas (Upper Silesia, Poland). Water Air Soil Poll 226(6):189. doi:10.1007/s11270-015-2445-Z

Li X, Poon C, Liu PS (2001) Heavy metal contamination of urban soils and street dusts in Hong Kong. Appl Geochem 16(11-12):13611368. doi:10.1016/S0883-2927(01)00045-2

Lindsay WL, Norvell WA (1978) Development of a DTPA soil test for zinc, iron, manganese, and copper. Soil Sci Soc Am J 42:421-428

Liu X, Song Q, Tang Y, Li W, Xu J, Wu J, Wang F, Brookes PC (2013) Human health risk assessment of heavy metals in soil-vegetable system: a multi-medium analysis. Sci Total Environ 463-464:530 540. doi:10.1016/j.scitotenv.2013.06.064

Maiz I, Arambarri I, Garcia R, Millán E (2000) Evaluation of heavy metal availability in polluted soils by two sequential extraction procedures using factor analysis. Environ Pollut 110(1):3-9. doi:10.1016/ S0269-7491(99)00287-0

Malczyk P, Kędzia W (1996) Heavy metals in forest soils along exit road Bydgoszcz-Inowrocław. Soil Sci Ann 47(3/4):203-211

McGrath D (1996) Application of single and sequential extraction procedures to polluted and unpolluted soils. Sci Total Environ 178:37-44. doi:10.1016/0048-9697(95)04795-6

Müller G (1969) Index of geoaccumulation in sediments of the Rhine River. GeoJournal 2:108-118

Othman I, Al-Oudat M, Al-Masri MS (1997) Lead levels in roadside soils and vegetation of Damascus city. Sci Total Environ 207(1):43-48. doi:10.1016/S0048-9697(97)00243-X

Pagotto C, Rémy N, Legret M, Le Cloirec P (2001) Heavy metal pollution of road dust and roadside soil near a major rural highway. Environ Technol 22:307-319. doi:10.1080/095933322208618280

Pallavi P, Harrison RM (2013) Estimation of the contribution of road traffic emissions to particulate matter concentrations from field measurements: a review. Atmos Environ 77:78-97. doi:10.1016/j. atmosenv.2013.04.028

Regulation of the Minister of the Environment dated 1 September 2016 on assessment procedures for the land surface pollution. (Regulation No. 1395)

Rosada J (2007) Environmental aspects of the use of the areas affected by the emissions of copper smelters to agricultural crops. Progress in Plant Protection 47(1):119-127

Saeedi M, Li L, Salmanzadeh M (2012) Heavy metals and polycyclic aromatic hydrocarbons: pollution and ecological risk assessment in street dust of Tehran. J Hazard Mater 227:9-17. doi:10.1016/j. jhazmat.2012.04.047

Salminen R, Gregorauskienè V (2000) Considerations regarding the definition of a geochemical baseline of elements in the surficial materials in areas differing in basic geology. Appl Geochem 15:647-653. doi:10.1016/S0883-2927(99)00077-3

Salminen R, Tarvainen T (1997) The problem of defining geochemical baselines. A case study of selected elements and geological materials in Finland. J Geochem Explor 60(1):91-98. doi:10.1016/ S0375-6742(97)00028-9

Sezgin N, Ozcan HK, Demir G, Nemlioglu S, Bayat C (2004) Determination of heavy metal concentrations in street dusts in Istanbul E-5 highway. Environ Int 29(7):979-985. doi:10.1016/ S0160-4120(03)00075-8

Shi G, Chen Z, Bi C, Li Y, Teng J, Wang L, Xu S (2010) Comprehensive assessment of toxic metals in urban and suburban street deposited sediments (SDSs) in the biggest metropolitan area of China. Environ Pollut 158(3):694-703. doi:10.1016/j.envpol.2009.10.020

Sierra M, Martínez FJ, Aguilar J (2007) Baselines for trace elements and evaluation of environmental risk in soils of Almería (SE Spain). Geoderma 139:209-219. doi:10.1016/j.geoderma.2007.02.003 
Sterckeman T, Gomez A, Ciesielski H (1996) Soil and waste analysis for environmental risk assessment in France. Sci Total Environ 178:6369. doi:10.1016/0048-9697(95)04798-0

Temmerman L, Vanongeval L, Boon W, Hoenig M (2003) Heavy metal content of arable soil in northern Belgium. Water Air Soil Poll 148(1):61-76. doi:10.1023/A:1025498629671

Trujillo-González JM, Torres-Mora MA, Keesstra S, Brevik EC, Jiménez-Ballesta R (2016) Heavy metal accumulation related to population density in road dust samples taken from urban sites under different land uses. Sci Total Environ 553:636-642. doi:10.1016/j. scitotenv.2016.02.101

Uniejewska M (1982) Detailed Geological Map of Poland. Polish Geological Institute. National Research Institute. 245 Grudziądz

USDA-United States Department Of Agriculture (2012) Soil Survey Manual. Scientific Publishers Journal Department

Wawer M, Magiera T, Ojha G, Appel E, Bućko MS, Kusza G (2015) Characteristics of current roadside pollution using test-monitoring plots. Sci Total Environ 505:795-804. doi:10.1016/j.scitotenv.2014. 10.025

Wei L, Tieyu W, Yonglong L, John PG, Yajuan S, Yuanming Z (2007) Landscape ecology of the Guanting Reservoir, Beijing, China: multivariate and geo-statistical analyses of metals in soils. Environ Pollut 146:567-576. doi:10.1016/j.envpol.2006.08.001

Wei B, Yang L (2010) A review of heavy metal contaminations in urban soils, urban road dusts and agricultural soils from China. Microchem J 94(2):99-107. doi:10.1016/j.microc.2009.09.014

Werkenthin M, Kluge B, Wessolek G (2014) Metals in European roadside soils and soil solution - a review. Environ Pollut 189:98-110. doi: 10.1016/j.envpol.2014.02.025

Woś A (2010) Polish climate in the second half of $X^{\text {th }}$ century. UAM Scientific Publishing, Poznań

Wuana RA, Okieimen FE (2011) Heavy metals in contaminated soils: a review of sources, chemistry, risks and best available strategies for remediation. ISRN Ecology 1-20 